\section{The EfFect OF EXternal Suction at the Dust OUtLet OF A CYCLONE}

\author{
M. Dewikaa, M. Rashidb*, N. Hasyimahb
}

asunway University, Jalan Universiti, Bandar Sunway, 47500 Petaling Jaya, Selangor, Malaysia

bAir Resources Research Laboratory, Malaysia-Japan International Institute of Technology, 54100 Kuala Lumpur,
Article history

Received

7 December 2016

Received in revised form

11 June 2017

Accepted

10 August 2017

*Corresponding author rashidyusof.kl@utm.my Malaysia

\section{Graphical abstract}

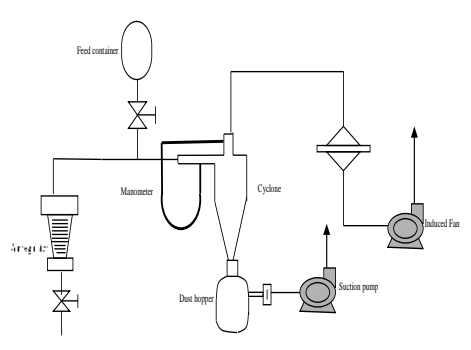

\begin{abstract}
Cyclone is one of the most commonly used particulate dust collectors in industries. It employs centrifugal force generated by a spinning gas stream to separate the particulate matter from the carrier gas. However, cyclone is efficient to collect coarse rather than fine particulate size fraction. In this regard, a study was carried out to determine the effect of creating more negative pressure at the storage hopper of a $100 \mathrm{~mm}$ diameter laboratory scale cyclone. The negative pressure was created by drawing out a small portion of the gas stream by means of an air pump attached to the storage hopper. Results showed that there was exponentially related between the pressure drop $(\Delta \mathrm{P})$ and the amount of gas stream drawn at the storage hopper, but with an increment of $2.6 \%$ with suction compared to without. Interestingly, it was observed that more of the fine particulate matter was drawn from the gas stream as the suction flow rate increases. This is due to the suction velocity which exceeds the terminal falling velocities of the fine particles size range. There was a reduction by weight in the fine particle emitted from the cyclone ranging between $14 \%$ to $52 \%$ by introduction of the suction. The finding serves as a basis for future work in reducing fine particulates from a cyclone separator.
\end{abstract}

Keywords: Air pollution, cyclone, suction, increase efficiency, pressure drop

\begin{abstract}
Abstrak
Siklon adalah salah satu daripada pengumpul debu zarah paling biasa digunakan dalam industri. la menggunakan daya emparan yang dihasilkan oleh putaran aliran gas untuk memisahkan bahan zarah dari gas pembawa. Walau bagaimanapun, siklon cekap untuk mengumpul zarah kasar berbanding saiz zarah yang halus. Dalam hal ini, satu kajian telah dijalankan untuk menentukan kesan mewujudkan tekanan yang lebih negatif pada corong penyimpanan berdiameter $100 \mathrm{~mm}$ siklon skala makmal. Tekanan negatif telah dicipta dengan mengeluarkan sebahagian kecil daripada aliran gas melalui pam udara yang dilekatkan pada corong penyimpanan. Hasil kajian menunjukkan bahawa terdapat hubungan yang eksponen antara kejatuhan tekanan $(\triangle P)$ dan jumlah aliran gas terkeluar pada corong penyimpanan, tetapi dengan peningkatan yang sangat kecil sebanyak $2.6 \%$ dengan sedutan berbanding tanpanya. Menariknya, ia telah diperhatikan bahawa lebih banyak zarah halus dikeluarkan daripada aliran gas semasa kadar aliran sedutan meningkat. Ini adalah kerana halaju sedutan yang melebihi terminal halaju jatuh daripada rangkaian zarah bersaiz halus. Terdapat penurunan dalam pembebasan zarah halus dari siklon dalam lingkungan antara $14 \%$ hingga $52 \%$ dengan pengenalan sedutan. Penemuan ini berfungsi sebagai asas untuk kerja-kerja akan datang dalam mengurangkan partikel halus dari pemisah siklon.

Kata kunci: Pencemaran udara, siklon, sedutan, tingkatkan kecekapan, kejatuhan tekanan
\end{abstract}

(C) 2017 Penerbit UTM Press. All rights reserved 


\subsection{INTRODUCTION}

Cyclone is among the most widely used dust collector in industries because they are relatively simple and inexpensive to make. They are operated at moderate pressure losses and can give long trouble free service. It is a device without any moving parts in where the velocity of an inlet gas stream is transformed into a confined vortex from which centrifugal forces tend to drive suspended particles against the wall of cyclone body. As the main vortex spiral downwards, a quantity of gas is drawn off radially inward to feed a smaller vortex which spirals upwards to the clean gas discharge tube. This inner vortex is known as ascending vortex. Particle collide with inner wall of a cyclone, slide down and are collected in a dust hopper. These particles fall freely under the influence of gravitational force [1-7].

The collection efficiency of a cyclone increase with particle size, particle density, inlet gas velocity, cyclone body length, number of revolutions and smoothness of the cyclone wall. A higher efficiency cyclone requires a higher pressure drop and as a result more particle would be collected [8].

There are number of modification which could be made to increase the collection efficiency of a cyclone. This include by modifying the cyclone separator's exhaust under different contracting and sloping angles [9], increasing the vortex length [10], introducing a new geometry of reverse-flow gas cyclone with a partial recirculation system [11], increasing from one to three inlet [7], design with a spiral inlet [12] and design with a square cyclone [13]. In addition it is expected that by creating more negative pressure in the cyclone, the performance of the cyclone will increase. Thus this study reports the performance of a cyclone by creating more negative pressure at the dust outlet i.e. hopper of a $100 \mathrm{~mm}$ diameter cyclone.

\subsection{METHODOLOGY}

\subsection{Experimental Setup}

The study was carried out in laboratory using a pilot scale cyclone system as illustrated in Figure 1. The system consists of $100 \mathrm{~mm}$ diameter cyclone, a feed container, an air blower, a dust filter and an air regulator. The cyclone was made following the Swift's high collection efficiency configurations [14]. A specially fabricated air tight dust hopper is attached as the hopper of the cyclone. It is a collection bottle with an ID of $76 \mathrm{~mm}$ which has been fabricated with a $9 \mathrm{~mm}$ internal diameter outlet at one side of the bottle connected to a filter membrane, rotameter (at suction pump) and with maximum external suction of $0.9 \mathrm{~m}^{3} / \mathrm{hr}$. A $245 \times 230 \mathrm{~mm}$ back up filter is attached to the system to measure the amount of dust emitting the cyclone under various experimental conditions. The cyclone air regulator and the external suction rotameter were calibrated using a dry gas meter. The pressure drop across the cyclone was measured using a U-tube water manometer attached to the inlet and outlet of the cyclone.

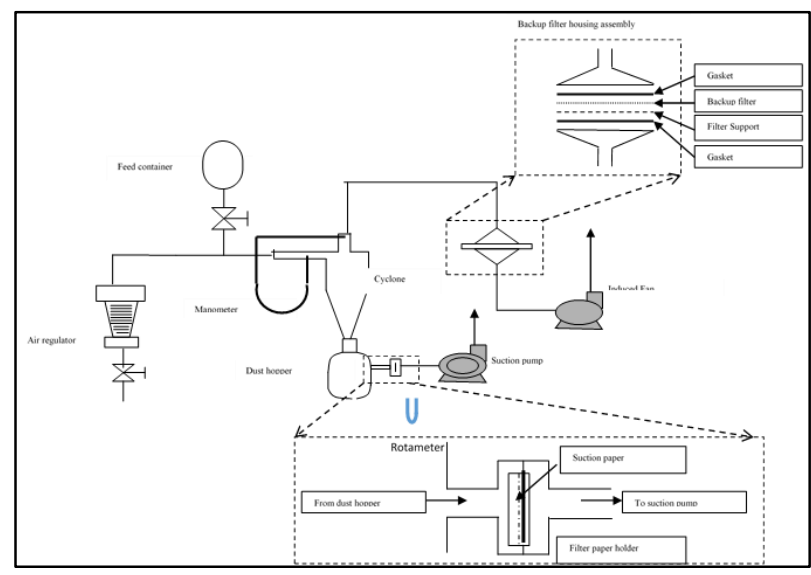

Figure 1 Experimental Setup

\subsection{Experimental Procedure}

Firstly, the experiment was conducted to measure the pressure drop across the cyclone with and without an external air suction at the dust hopper of the unit where no particle sample was introduced at this stage. The pressure drop was determined under various cyclone air volumetric flow rates (i.e. 9, 12, 15 and $18 \mathrm{~m}^{3} / \mathrm{hr}$ ). Similarly, the above experimental procedure was repeated by introducing an external air suction (i.e. $0.3,0.6$, and $0.9 \mathrm{~m}^{3} / \mathrm{hr}$ ) at the dust hopper with respect to each of the cyclone air flowrate.

A sample of coarse particle, CP (i.e. dried sand between sizes $150 \mu \mathrm{m}$ to $300 \mu \mathrm{m}$ ) and fine particle, FP (i.e. talcum powder, with $80 \%$ weight basis below than $75 \mu \mathrm{m})$ were used in this experiment. Both samples have a similar particle density of $1.5 \mathrm{~g} / \mathrm{cm}^{3}$ determined using a micro-pycnometer, but with different texture that easily distinguished from each other.

A stated CP amount of 50, 100 and $150 \mathrm{~g}$ sample was introduced at constant mass flowrate for each cyclone air volumetric flow rate as above, where the total amount of particle collected at the dust hopper was determined. A similar experimental procedure was repeated under the influence of various external suctions applied at the dust hopper for each cyclone air flow rate.

In order to study the effect of particle size on the performance of the cyclone (with and without external suction), a mixture of FP and CP was introduced in the study. Different weight composition of FP constituting 1\%, 3\% and $5 \%$ of the $100 \mathrm{~g}$ sample mixture was considered following the above experimental procedures. In addition, the amount of particle collected on the backup filter paper was determined to study the collection efficiency of the 
cyclone on the FP size fraction. In all cases, each of the experiment was repeated thrice and the average value was reported.

\subsection{RESULTS AND DISCUSSION}

\subsection{General Observations on Pressure Drop of the Cyclone}

Table 1 presents the pressure drop across the cyclone as a function of the inlet velocity obtained from this experiment compared to other theoretical pressure drop models where it is observed that the experimental pressure drop model was more conservative compared to the literatures.

The pressure drop was calculated based on Equation 1, [14].

$\Delta \mathrm{P}=\frac{1}{2} \mathrm{H}_{\mathrm{v}} \mathrm{V}_{\mathrm{i}}^{2} \rho_{\mathrm{g}}$ ...Equation 1

where $\mathrm{H}_{\mathrm{v}}$ is pressure drop expressed in number of inlet velocity heads, $V_{i}$ is inlet gas velocity $(\mathrm{m} / \mathrm{s})$ and $\rho_{g}$ is gas density $\left(\mathrm{kg} / \mathrm{m}^{3}\right)$. The inlet velocity is determined from the volumetric flowrate divide by the cross section inlet area of the cyclone.

The $\mathrm{Hv}$, pressure drop is calculated by the following Equation 2.

$\mathrm{H}_{\mathrm{V}}=\mathrm{K} \frac{\mathrm{HW}}{\mathrm{D}_{\mathrm{e}}^{2}}$ ...Equation 2

where $\mathrm{H}$ is height $(390 \mathrm{~mm}), \mathrm{W}$ is width $(100 \mathrm{~mm}), \mathrm{De}$ is exit diameter $(40 \mathrm{~mm})$ and $\mathrm{K}$ is a constant taken as 16 .

Table 1 Pressure drop equation cross cyclone of this experiment compared to other models from literatures

\begin{tabular}{ll}
\hline This study's experimental data & $\Delta P=6.64 \mathrm{vi}^{2}$ \\
Sherperd and Lapple (1939) & $\Delta \mathrm{P}=6.12 \mathrm{vi}^{2}$ \\
First (1950) & $\Delta \mathrm{P}=5.38 \mathrm{vi}^{2}$ \\
Alexander (1949) & $\Delta \mathrm{P}=3.77 \mathrm{vi}^{2}$ \\
Stairmand (1949) & $\Delta \mathrm{P}=4.26 \mathrm{vi}^{2}$ \\
\hline
\end{tabular}

Figure 2 is the graphical presentation of Table 1 clearly showed that the pressure drop of the cyclone increases with increase of the cyclone's flowrates or inlet velocity $[2,12]$. It clearly depicts the experimental model was nearest to Sherperd and Lapple pressure drop model with a difference of $18 \%$ and represents the highest pressure drop estimation compared to the other models.

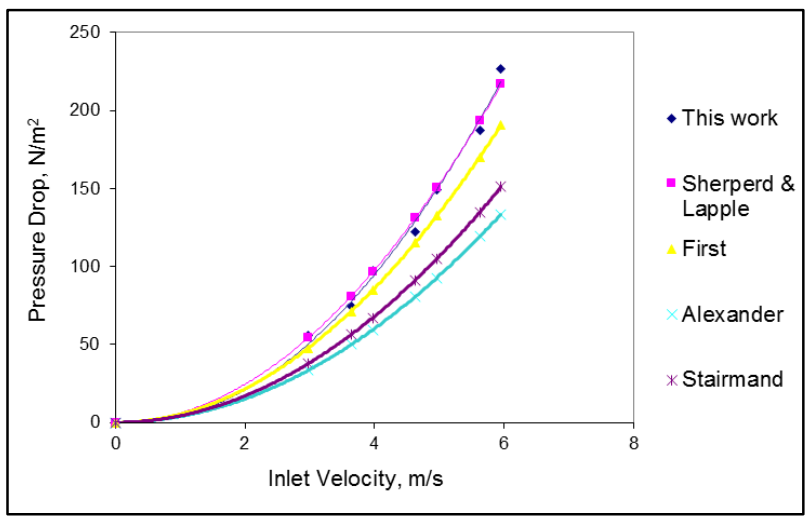

Figure 2 The theoretical and experimental pressure drop across cyclone with respect to cyclone's inlet velocity

\subsection{General Observations on Pressure Drop of the Cyclone Upon Introducing External Suction}

Table 2 presents the linear pressure drop equation for cyclone flow rates at varied external suction where notably it indicates the ascending order in magnitude of the gradient from low to a higher cyclone flow rate. At the highest cyclone flow rate of $Q=18 \mathrm{~m}^{3} / \mathrm{hr}$ the difference in the pressure drop with and without suction was $2.6 \%$. As a comparison, this was only $0.9 \%$ for the lowest cyclone flow rate of $Q=9 \mathrm{~m}^{3} / \mathrm{hr}$. The difference was more pronounced for the higher cyclone flow rates.

Table 2 The linear pressure drop equation for cyclone flow rates at varied external suction

\begin{tabular}{ccc}
\hline $\begin{array}{c}\text { Cyclone Flow } \\
\text { rate }\left(\mathbf{m}^{3} / \mathbf{h r}\right)\end{array}$ & Equation & Gradient \\
\hline 18 & $\mathrm{y}_{18}=6.54 \mathrm{x}+229$ & 6.54 \\
17 & $\mathrm{y}_{17}=4.59 \mathrm{x}+188$ & 4.59 \\
14 & $\mathrm{y}_{14}=4.22 \mathrm{x}+122$ & 4.22 \\
12 & $\mathrm{y}_{12}=2.91 \mathrm{x}+97$ & 2.91 \\
11 & $\mathrm{y}_{11}=2.49 \mathrm{x}+76$ & 2.49 \\
9 & $\mathrm{y}_{9}=0.54 \mathrm{x}+54$ & 0.55 \\
\hline
\end{tabular}

Note: $y=a x+b$ where $y$ is pressure drop across the cyclone, $x$ is the suction flow rate, $a$ is the gradient and $b$ is the intercept (when suction is zero)

Figure 3 presents the comparison between pressure drop across the cyclone with and without suction in the dust hopper, whereas stated earlier, there was a slight increase in the pressure drop by having the external suction in the system. This graph was generated by operating at condition of maximum suction i.e. at $\left(0.9 \mathrm{~m}^{3} / \mathrm{hr}\right)$ and no external suction. This is probably due to the external suction that pulls out some portion of air from the dust hopper, which creates a suction zone-nearing vacuum in the dust hopper. 


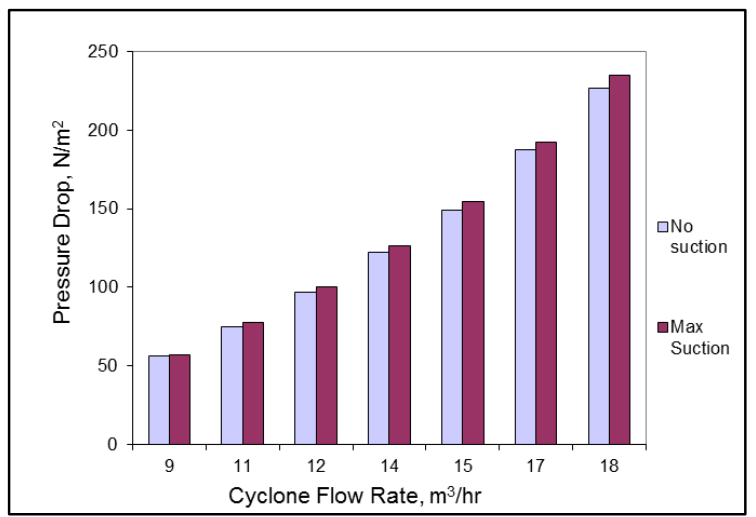

Figure 3 Pressure drop versus cyclone flow rate with and without suction

It is found that there was a difference in pressure drop across the cyclone between the results with and without the external suction. In this case, the plot of the experiments with external suction fits a quadratic equation as presented in $\Delta P=6.89 \mathrm{~V}^{2}$, which has a slightly higher gradient compared to the one without suction $\Delta P=6.64 \mathrm{~V}^{2}$. The finding suggests that there was an increment in the pressure drop across the cyclone by introducing an external suction.

\subsection{The Overall Collection Efficiency Without Suction}

The overall collection efficiency of the cyclone was investigated under both conditions, with and without external suction at the dust hopper of the cyclone. Sample of coarse particle (CP), and a mixture of coarse and fine particle (FP) were introduced under various cyclone flow rates. The collection efficiency was determined using Equation 3

$\eta=\frac{m_{\text {collected }}}{m_{\text {feed }}} \times 100 \%$

...Equation 3

where $m_{\text {collected }}$ is referring to mass collected in the dust hopper after the experiment, meanwhile mfeed is the amount of mass fed into the cyclone before the commencement of the experiment. Some presentation of data was done in amount of mass collected in the dust hopper, which also reflect the collection efficiency, where the higher the mass of samples collected, the higher the collection efficiency.

Figure 4 shows the amount of particle collected in the dust hopper under various cyclone flow rates and the amount of $\mathrm{CP}$ fed into the system which shows that the amount of particle collected (i.e. collection efficiency) increases with cyclone flow rates as similarly reported by others [15-17]. The increase in the amount of the particle collected by the cyclone with the increase in the volumetric flow rate, the latter being influenced by the inlet velocity. Increased volumetric flow rate, increases the inlet velocity which in turn increases in the speed of vortex rotation, thus contributing to a higher cyclone collection efficiency [16].

Also as in Figure 4, a higher loading of sample introduced contributes to a higher collection efficiency of the cyclone which is due to the particle collision in the cyclone as reported in literatures [1822].

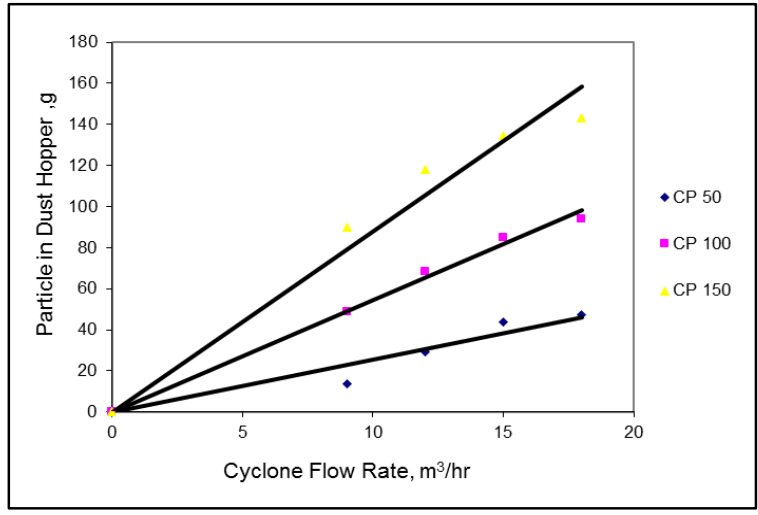

Figure 4 Particle collected in the cyclone dust hopper versus cyclone flow rate $Q$, with various mass of coarse particle

Figure 5 shows cyclone collection efficiency versus cyclone flow rate for various percentages of fine particles in the total amount of $100 \mathrm{~g}$ of the sample, where similar to the trend reported previously, the collection efficiency increases with the cyclone flow rate. As expected, the collection efficiency of the cyclone is higher for a mixture of sample with a lower percentage of fine particles (i.e. higher percentage of coarse particle in the admixture).

The collecting forces developed in the cyclone are particularly effective on large particles where the swirling motion in the cyclone carries the coarse particles towards the inner wall of the cyclone creating collision that causes the particle to finally fall into the dust hopper. On the contrary, the fine particles will tend to follow the radially inward motion of the gas stream and escape out of the cyclone through the clean gas discharge outlet [3, 23]. Therefore, sample mixture with lowest amount of fine particles (i.e. 1\%FP) will have higher collection efficiency compared to sample with highest percentage of fine particles (i.e. $5 \%$ FP) as depicted in Figure 5. 


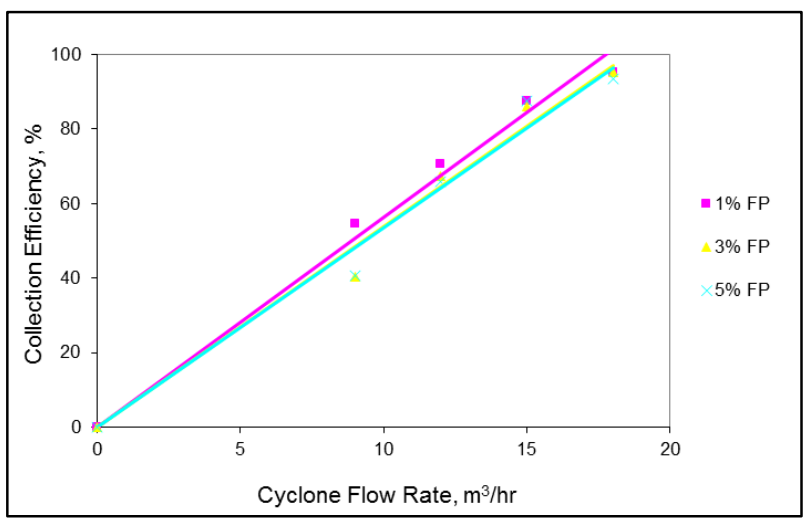

Figure 5 Collection efficiency versus cyclone flow rate for various percent of FP

\subsection{The Overall Collection Efficiency with External Suction}

Figure 6 presents the overall collection efficiency of the cyclone versus suction flow rate for $100 \mathrm{~g}$ of $\mathrm{CP}$ introduced into the cyclone which showed that there is an increase in the total amount (i.e. a sum of mass collected in the dust hopper and suction stream) of particles collected. However the increment seems to be marginal due to the fact that the applied suction flow rate was relatively small compared to the cyclone flow rate due to the limitation of the suction pump used. A similar trend was also observed for different amount of $\mathrm{CP}$ fed into the cyclone (i.e. 50 and $150 \mathrm{~g}$ ) during the experiment.

Although the difference in the collection efficiency with and without suction was marginal (i.e. varied from $0.7-3 \%)$ the findings illustrate that applying suction enhances the overall collection efficiency of the cyclone. A more meaningful observation could have been obtained if a high percentage of suction for higher cyclone flow rates could have been experimented. It is anticipated that higher suction and at the higher cyclone flow rates would give a better result as the former further enhanced the total collection efficiency of the cyclone.

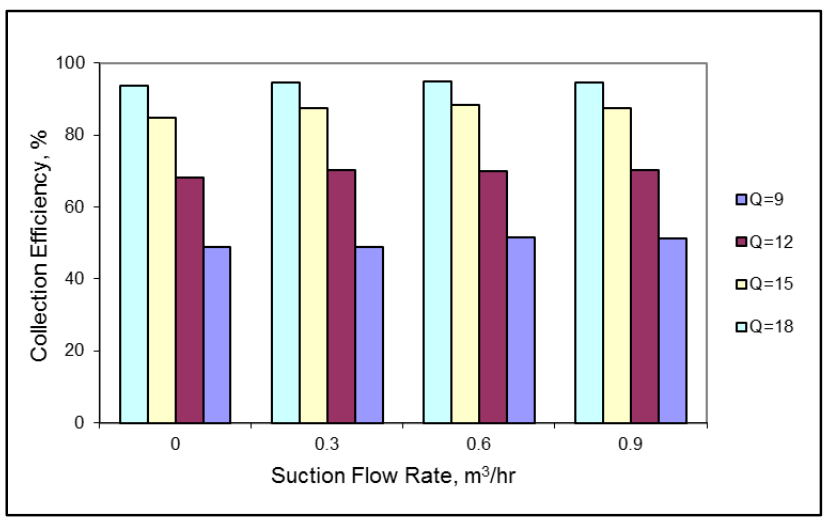

Figure 6 Collection efficiency versus suction flow rate under various cyclone flow rates, $\mathrm{Q}$ for $100 \mathrm{~g}$ of $\mathrm{CP}$
Figure 7 presents the overall collection efficiency (i.e. weight in dust hopper and suction stream) of the cyclone versus suction flow rate for selected percentage of FP at fixed cyclone flow rate of $18 \mathrm{~m}^{3} / \mathrm{hr}$ which showed there is an increase in collection efficiency with suction flowrate. A similar trend was observed for all other cyclone flow rates (i.e. 9,12 and $15 \mathrm{~m}^{3} / \mathrm{hr}$ ). However, the overall collection efficiency is rather low as the FP percentage increases. This is as expected as cyclone is known to have less collection efficiency on fine particle [1, 2427]. As in Figure 7, more of the FP size fraction was collected with the increase in suction flowrate illustrating enhancement of FP collection with the introduction of external suction at the dust hopper. In addition, as demonstrated in the figure, suction stream has the ability to be selectively collect fine particle rather than coarse particle size fraction.

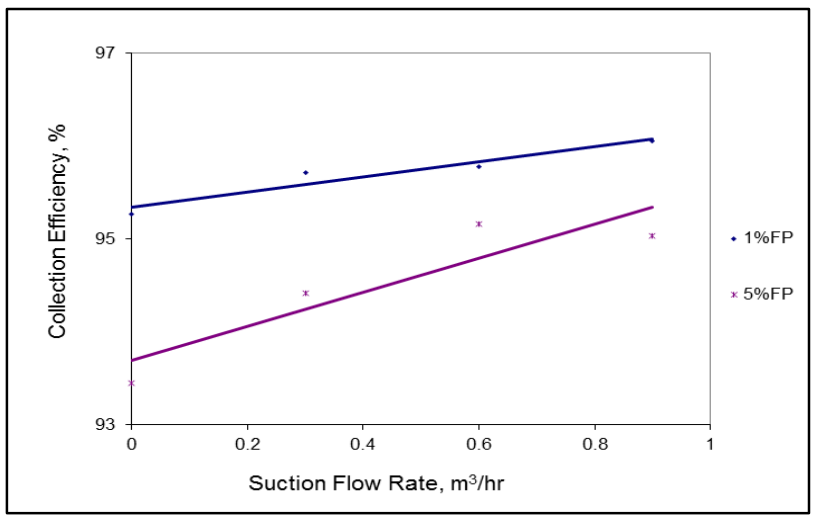

Figure $\mathbf{7}$ Overall collection efficiency versus suction flow rate for selected percentage of FP with fixed cyclone flow rate of Q, $18 \mathrm{~m}^{3} / \mathrm{hr}$

\subsection{Particle Collection on the Suction Filter Paper}

Figure 8 presents the mass of particle collected in the suction stream at various cyclone flow rates (i.e. 9, 12, 15 and $18 \mathrm{~m}^{3} / \mathrm{hr}$ ) for a fixed amount of $100 \mathrm{~g} \mathrm{CP}$ sample, where it was observed that the cyclone flow rate influences the amount of sample collected in the suction stream. As previously stated, the amount of particles collected was higher at a higher cyclone flow rate. In addition, the mass of particles collected on the suction filter paper increases with the increase in suction for a fixed cyclone flow rate. It seems that more particles are carried into the cyclone at higher gas flow rate and with introduction of the suction stream at the dust hoper enhanced the amount of particles collected probably due to the pulling of the vortex further down into the hopper. Some of these free falling $\mathrm{CP}$ followed the suction stream and collected on the suction filter paper. A similar trend was observed for different amount of CP introduced into the cyclone (i.e. 50 and $150 \mathrm{~g}$ ). 


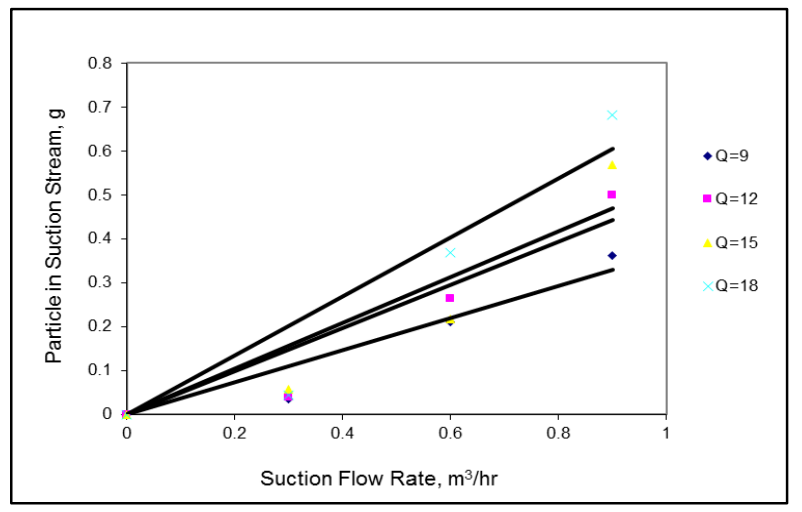

Figure $\mathbf{8}$ Particle collected in suction stream versus suction at various cyclone flow rates, $Q$

A similar observation was obtained when the experiments were repeated with mixture of FP and CP samples. As depicted in Figure 9, assuming a linear relationship between mass collected and suction flow rates, more particles were collected in the suction stream when more the FP was introduced in the sample for a fixed cyclone flow rate of $18 \mathrm{~m}^{3} / \mathrm{hr}$. A similar trend was also observed for other cyclone flow rates. It was observed that more of the FP size fraction is collected with the increasing of the external suction which creates lower pressure that enables both the cyclone's inner and outer vortices to travel further down into the dust hopper. This creates disturbance in the vortices, consequently shedding off particles to fall freely at their terminal falling velocities into the hopper and suction stream.

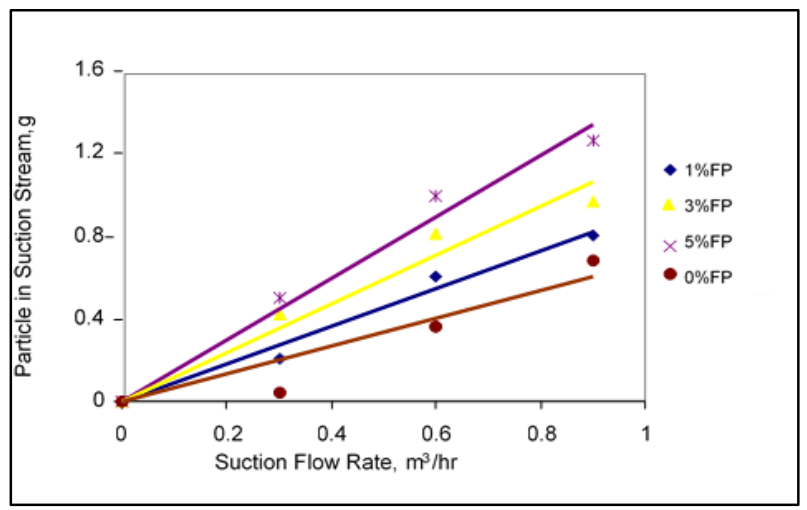

Figure 9 Particle collected in suction stream versus suction flow rate for various compositions of sample with fixed cyclone flow rate of $Q, 18 \mathrm{~m}^{3} / \mathrm{hr}$

However, major portion of falling FP are being extracted out from the dust hopper into the suction stream based on terminal falling velocity of a particle which is a function of density and size of the particle $[14,28]$. Based on a micro pycnometer analysis, both the FP and CP have a similar density but with different particle size fraction of $\leq 75 \mu \mathrm{m}$ and $\geq 150 \mu \mathrm{m}$, respectively. Thus, FP that is categorized as a smaller diameter has a smaller terminal falling velocity which is easier to be extracted and collected into the suction stream compared to CP.

\subsection{Particle Collection on the Backup Filter Paper}

To further support the previous findings, studies on the mass of particles that escaped from the clean gas discharge of the cyclone and collected on the backup filters were scrutinized. Figure 10 presents the mass of particles collected on the backup filter versus suction flow rates for various percentage of FP with a fixed cyclone flow rate which showed a decrease in FP collected onto the backup filter with increasing suction flow rate. This finding clearly indicates that the introduction of external suction flowrate helped to reduce fine particle emission from the cyclone.

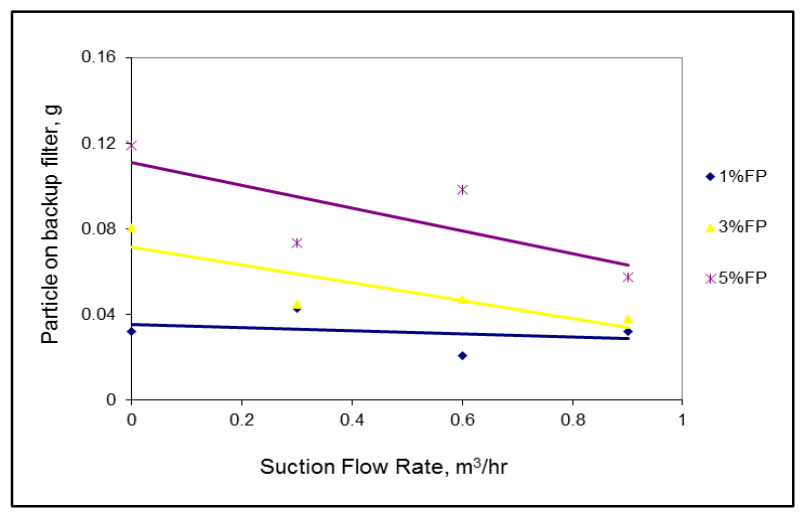

Figure 10 Mass particle collected on the backup filter versus suction flow rate for various composition of sample with fixed cyclone flow rate of $Q=18 \mathrm{~m}^{3} / \mathrm{hr}$

Table 3 presents the percentage reduction of particulate mass on the backup filter with and without suction for 5\% FP sample mixture which showed that there was a reduction on mass collected at the backup filter ranging from 13.6 up to $51.5 \%$ for cyclone flow rates between 9 to $18 \mathrm{~m}^{3} / \mathrm{hr}$. Again this indicates that the cyclone flow rate under the influence of suction also play an important role in the reduction of the total particle emission. This finding suggests that the overall collection efficiency of a cyclone can be further enhanced by introducing external suction at the dust hopper.

Table 3 Percentage of reduction of particulate mass with and without suction on the backup filter

\begin{tabular}{cccc}
\hline $\begin{array}{c}\text { Cyclone } \\
\text { flow rate } \\
\left(\mathbf{m}^{3} / \mathbf{h r}\right)\end{array}$ & $\begin{array}{c}\text { Particle } \\
\text { collected } \\
\text { with no } \\
\text { suction }(\mathbf{g})\end{array}$ & $\begin{array}{c}\text { Particle } \\
\text { collected with } \\
\text { maximum } \\
\text { suction }(\mathbf{g})\end{array}$ & $\begin{array}{c}\% \\
\text { Reduction }\end{array}$ \\
\hline 18 & 0.119 & 0.0577 & 51.50 \\
15 & 0.1211 & 0.0649 & 46.40 \\
12 & 0.0723 & 0.0612 & 15.40 \\
9 & 0.0562 & 0.0485 & 13.70 \\
\hline
\end{tabular}




\subsection{CONCLUSION}

The introduction of the suction stream in the dust hopper of a cyclone brings about a slight increase in pressure drop across the cyclone which also increase the performance of a cyclone. The study also showed that the increase in pressure drop was influenced not merely by the cyclone's flow rate but also by the suction flow rate applied at the dust hopper. The study found that there was a linear relationship between the suction flow rate and the mass of particle drawn by the suction stream. More of the fine particle size fraction was collected in the suction stream when a higher percentage of it was introduced into the cyclone. The study concludes that the suction stream has a higher 'selectivity' towards the fine rather than the coarse due to the difference in the terminal falling velocities of particles with respect to the suction flowrate. The introduction of the suction also plays an important role in the reduction of the total particulate mass emitting from the cyclone ranging from 14 to $52 \%$ compared to the one without any suction. This concludes that the introduction of suction reduces particulate released from a cyclone. Finally, this study serves as a basis for future research in increasing the performance of a cyclone in real plant situations to comply with the stringent particulate emission regulations.

\section{References}

[1] Avci, A., \& Karagoz, I. 2003. Effects of Flow and Geometrical Parameters on the Collection Efficiency in Cyclone Separators. Journal of Aerosol Science. 34: 937955.

[2] Azadi, M., \& Azadi, M. 2012. An Analytical Study of the Effect of Inlet Velocity on the Cyclone Performance Using Mathematical Models. Powder Technology. 217: 121-127.

[3] Brar, L. S., Sharma, R. P., \& Dwivedi, R. 2015. Effect of Vortex Finder Diameter on Flow Field and Collection Efficiency of Cyclone Separators. Particulate Science and Technology. 33(1): $34-40$

[4] Darcovich, K., Jonasson, K. A., \& Capes, C. E. 1997. Developments in the Control of Fine Particulate Air Emissions. Advanced Powder Technology. 8(3): 179-215.

[5] Hsiao, T. C., Huang, S. H., Hsu, C. W., Chen, C. C., \& Chang, P. K. 2015. Effects of the Geometric Configuration on Cyclone Performance. Journal of Aerosol Science. 86: 1-12.

[6] Tsai, C. J., Chen, D. R., Chein, H., Chen, S. C., Roth, J. L., Hsu, Y. D., Biswas, P. 2004. Theoretical and Experimental Study of an Axial Flow Cyclone for Fine Particle Removal in Vacuum Conditions. Journal of Aerosol Science. 35(9): 1 105-11 18.

[7] Winfield, D., Cross, M., Croft, N., Paddison, D., \& Craig, I. 2013. Performance Comparison of a Single and Triple Tangential Inlet Gas Separation Cyclone: A CFD Study. Powder Technology. 235: 520-531.

[8] Karagoz, I., \& Avci, A. 2007. Modelling of the Pressure Drop in Tangential Inlet Cyclone Separators. Aerosol Science and Technology. 39(9): 857-865.
[9] Chen, J., \& Liu, X. 2010. Simulation of a Modified Cyclone Separator with a Novel Exhaust. Separation and Purification Technology. 73(2): 100-105.

[10] Karagoz, I., Avci, A., Surmen, A., \& Sendogan, O. 2013. Design and Performance Evaluation of a New Cyclone Separator. Journal of Aerosol Science. 59: 57-64.

[11] Salcedo, R. L. R., Chibante, V. G., Fonseca, A. M., \& Cândido, G. 2007. Fine Particle Capture in Biomass Boilers with Recirculating Gas Cyclones: Theory and Practice. Powder Technology. 172(2): 89-98.

[12] Zhoa, B., Shen, H., \& Kang, Y. 2004. Development of a Symmetrical Spiral Inlet to Improve Cyclone Separator Performance. Powder Technology. 145(1): 47-50.

[13] Su, Y., Zheng, A., \& Zhao, B. 2011. Numerical Simulation of Effect of Inlet Configuration on Square Cyclone Separator Performance. Powder Technology. 210(3): 293-303.

[14] Cooper, C David, Alley, F. C. 1986. Air Pollution Control. PWS Engineering. Boston.

[15] Baltrenas, P., Pranskevicius, M., \& Venslovas, A. 2015 Optimization of the New Generation Multichannel Cyclone Cleaning Efficiency. Energy Procedia. 72: 188-195.

[16] Kaya, F., Karagoz, I., \& Avci, A. 2011. Effects of Surface Roughness on the Performance of Tangential Inlet Cyclone Separators. Aerosol Science and Technology. 45(8): 988995.

[17] Safikhani, H., Shams, M., \& Dashti, S. 2011. Numerical Simulation of Square Cyclones in Small Sizes. Advanced Powder Technology. 22(3): 359-365.

[18] Buonanno, G., Scungio, M., Stabile, L., \& Tirler, W. 2012. Ultrafine Particle Emission from Incinerators: The Role of the Fabric Filter. Journal of the Air \& Waste Management Association. 62(1): 103-111.

[19] Fassani, F. L., \& Goldstein, L. 2000. A Study of the Effect of High Inlet Solids Loading on a Cyclone Separator Pressure Drop and Collection Efficiency. Powder Technology. 107(12): 60-65.

[20] Gimbun, J., Choong, T. S. Y., Fakhru'l-Razi, A., \& Chuah, T. G. 2004. Prediction of the Effect of Dimension, Particle Density, Temperature, and Inlet Velocity on Cyclone Collection Efficiency. Jurnal Teknologi. 40: 37-50.

[21] Hoffmann, A. C., \& Stein, L. E. 2008. Gas Cyclones and Swirl Tubes: Principles, Design and Operation. Springer.

[22] Iozia, D. L., \& Leith, D. 2007. Effect of Cyclone Dimensions on Gas Flow Pattern and Collection Efficiency. Aerosol Science and Technology. 37-41.

[23] Ganegama B. S., \& Leung, A. Y. T. 2015. CFD Simulation of Cyclone Separators to Reduce Air Pollution. Powder Technology. 286: 488-506.

[24] Hoffmann, A. C., de Jonge, R., Arends, H., \& Hanrats, C. 1995. Evidence of the "Natural Vortex Length" and its Effect on the Separation Efficiency of Gas Cyclones. Filtration \& Separation. 32(8): 799-804.

[25] Leith, D., \& Mehta, D. 1973. Cyclone Performance and Design. Atmospheric Environment. 7(5): 527-549.

[26] Molerus, O., \& Glückler, M. 1996. Development of a Cyclone Separator with New Design. Powder Technology. 86(1): 37-40.

[27] Ray, M. B., Luning, P. E., Hoffmann, A. C., Plomp, A., \& Beumer, M. I. L. 1998. Improving the Removal Efficiency of Industrial-Scale Cyclones for Particles Smaller Than Five Micrometre. International Journal of Mineral Processing. 53: 39-47.

[28] William C. Hinds. 1998. Aerosol Technology. 2nd ed. Wiley Interscience. 